\title{
FORMULASI LOSION EKSTRAK HERBA PEGAGAN (Centella Asiatica (L.) Urban) DAN UJI MUTU SERTA STABILITASNYA
}

\author{
Triyani Sumiati ${ }^{1 *}$, Ferry Effendy ${ }^{1}$, Eva Riani ${ }^{1}$ \\ 1Program Studi S1 Farmasi, Sekolah Tinggi Teknologi Industri dan Farmasi Bogor \\ *Korespondensi: triyanisumiati@gmail.com
}

\begin{abstract}
ABSTRAK
Pegagan merupakan salah satu jenis tanaman yang dapat digunakan sebagai bahan baku perawatan kulit. Pegagan dapat meregenerasi tingkat jaringan dengan mensintesis kolagen juga bermanfaat untuk perawatan kulit muka yang kering dan bersisik. Tujuan penelitian ini untuk memformulasikan ekstrak kental herba pegagan (Centella asiatica (L.) urban) menjadi sediaan losion serta menguji mutu, stabilitas dan aktivitas antioksidannya. Ekstraksi herba pegagan dilakukan dengan cara maserasi, formula losion dibuat dengan konsentrasi ekstrak herba pegagan 5\%. Sediaan yang dihasilkan diuji mutu, stabilitas selama 8 minggu pada suhu kamar $\left(25-30^{\circ} \mathrm{C}\right)$ dan menguji aktivitas antioksidannya. Hasil penelitian menunjukkan bahwa formula 2 losion herba pegagan memiliki mutu fisik warna, aroma, kehomogenan, $\mathrm{pH}$, viskositas, daya sebar dan daya lekat yang lebih baik dari formula 1 dan 3. Hasil uji stabilitas pada formula 2 losion herba pegagan memiliki stabilitas yang baik.
\end{abstract}

Kata kunci: Ekstrak, pegagan, losion, mutu, stabilitas

\begin{abstract}
ABSTRACK
Gotu Kola is one type of plant that can be used as a raw material for skin care. Gotu kola can connect the tissue level by synthesizing collagen also useful for the treatment of dry and scaly face skin. The purpose of this study was to formulate the Centellaasiatica (L.) urban herbaceous extract into a lotion dosage form and improve its quality, improve and strengthen its antioxidants. Gotu kola herb extraction was done by maceration, lotion formula was made with a concentration of gotu kola herb extract $5 \%$. The resulting preparations praise quality, for 8 weeks at room temperature $\left(25-30^{\circ} \mathrm{C}\right)$ and are guaranteed antioxidant activity. Formula 2 research shows that gotu kola herb lotion has color, aroma, homogeneity, $\mathrm{pH}$, viscosity, spreadability and adhesion which is better than formula 1 and 3 . The results of this study show that formula 2 gotu kola herb lotion has good ability.
\end{abstract}

Keywords: Extract, Centella asiatica, lotion, quality and stability

\section{PENDAHULUAN}

Indonesia merupakan negara tropis dengan sumber daya alam termasuk diantaranya tumbuh-tumbuhan yang sebagian telah dimanfaatkan baik untuk pencegahan atau pengobatan penyakit maupun kosmetik. Penggunaan tumbuhan sebagai zat aktif pada sediaan kosmetika sangat berkaitan dengan kandungan kimia yang terdapat dalam tambahan tersebut terutama zat bioaktif. Senyawa bioaktif yang terdapat pada tumbuhan biasanya merupakan metabolit sekunder seperti alkaloid, flavonoid, dan saponin (1). Salah satu jenis tanaman yang mempunyai arti penting dalam obat-obatan tradisional adalah herba pegagan. Pegagan mengandung zat saponin, asiatikosida, asam asiatat dan medekasat. Asiatikosida, bersama asam asiatik dan asam madekasik merupakan antioksidan yang kuat serta dapat meregenerasi tingkat jaringan dengan mensintesis kolagen dengan maksud dapat 
meringankan selulit, menghilangkan bintik hitam pada kulitwajah dan mengurangi keriput (2). Tanaman ini bisa digunakan sebagai bahan baku perawatan kulit muka yang kering dan bersisik. Perawatan kulit yang dimaksud adalah perawatan kulit yang mulai kusam, berkerut atau kulit yang mulai menunjukan tanda-tanda penuaan yang sangat tidak diinginkan, terutama oleh kaum perempuan yang selalu ingin tampil awet muda, cantik dan sehat. (3). Pada penelitian sebelumnya yang telah dilakukan Anita (4), konsentrasi 5\% ekstrak herba pegagan telah dilakukan pengujian sebagai antioksidan dalam sediaan krim. Berdasarkan uraian di atas untuk meningkatkan dalam penggunaannya maka akan dibuat suatu sediaan farmasi berupa losion yang digunakan untuk penggunaan yang lebih luas untuk seluruh permukaan kulit tubuh. Losion merupakan salah satu bentuk emulsi, didefinisikan sebagai campuran dari dua fase yang tidak bercampur, yang distabilkan dengan sistem emulsi dan jika ditempatkan pada suhu ruang berbentuk cairan yang dapat dituang dimaksudkan untuk digunakan pada kulit sebagai pelindung (5). Penelitian ini bertujuan untuk mengetahui mutu fisik sediaan losion dan menganalisis stabilitasnya.

\section{METODE}

\section{Bahan}

Bahan yang digunakan adalah Herba Pegagan, Bouchardat LP, Mayer LP, Dragendroff LP, etanol 95\%, serbuk magnesium $(\mathrm{Mg})$, asamklorida $2 \mathrm{~N}(\mathrm{HCl})$, asam klorida pekat, larutan gelatin $10 \%$, natrium klorida $10 \%(\mathrm{NaCl})$, asam asetat anhidrat, Etanol 70\%, Asam Stearat, Parafin cair, Setil alkohol, Gliserin, Trietanolamin, Metil paraben, Cera alba, Adepslanae, Propil paraben, Parafin cair, Dinatrium EDTA, Pengaroma, Air suling.

\section{Alat}

Peralatan yang digunakan adalah tabung reaksi, timbangan analitik, Grinder, ayakan mesh 40, kain batis, krus, tanur, kertas saring, cawan penguap, tangas air, mortar dan stamper, moisture balance, pipa corong, pipet tetes, botol plastik putih 100 $\mathrm{ml}$, rotary evaporator, spatula, batang pengaduk, gelas ukur, Kaca objek, kaca arloji, labu ukur $25 \mathrm{ml}$, termometer, bejana maserasi, viscometer Brookfield, $\mathrm{pH}$ meter, skin analyzer, TLC scanner.

\section{Prosedur Kerja Preparasi Sampel}

Bahan yang digunakan dalam penelitian ini adalah herba pegagan (Centella asiatica (L.) Urb). yang diperoleh dari BALITRO dan dipanen pada umur 6 bulan. Herba pegagan segar sebanyak $15 \mathrm{~kg}$ dikumpulkan dan disortasi basah lalu dicuci dengan air sampai bersih. Kemudian ditiriskan sampai tidak tersisa air. Herba yang sudah tiris, dikeringkan di bawah sinar matahari secara tidak langsungs elama 3 hari hingga didapatkan simplisia kering. Kemudian, simplisia kering diserbukkan menggunakan blender dan diayak dengan ayakan ukuran 60 mesh. Serbuk simplisia kemudian disimpan dalam wadah bersih dan ditutup rapat (6).

\section{Penetapan Kadar Air Simplisia}

Pemeriksaan kadar air dilakukan dengan menggunakan moisture balance. Sebanyak $1 \mathrm{~g}$ serbuk dimasukkan ke dalam alat yang telah disiapkan pada suhu $105^{\circ} \mathrm{C}$ selama 10 menit. Kadar yang tertera pada moisture balance kemudian dicatat (7).

\section{Pembuatan Ekstrak Kental Herba Pegagan}

Serbuk simplisia daun herba pegagan sebanyak $1 \mathrm{~kg}$ ditimbang, kemudian dimaserasi menggunakan pelarut etanol $70 \%$, caranya dengan merendam serbuk simplisia selama 3 x 24 jam. Setiap 24 jam maserat disaring, kemudian ditambahkan lagi pelarut etanol $70 \%$ sampai 3 kali ulangan. Hasil maserasi kemudian dipekatkan menggunakan rotary evaporator pada suhu $50^{\circ} \mathrm{C}$ sampai diperoleh ekstrak kental daun pegagan. Kemudian dihitung rendemen ekstrak total. Rendemen ekstrak total dihitung dengan membagi berat ekstrak yang dihasilkan dengan berat simplisia serbuk (6). Perhitungan rendemen ekstrak total dapat dilakukan berdasarkan persamaan berikut: 
64 Triyani Sumiati et al., (Formulasi Losion Ekstrak Herba Pegagan...)

$$
\% \text { Rendemen ekstrak total }=\frac{\text { Bobot ekstrak yang diperoleh }}{\text { Bobot simplisia serbuk }} \times 100 \%
$$

\section{Penapisan Fitokimia Ekstrak Bonggol Nanas (1)}

Ekstrak yang diperoleh dilakukan uji fitokimia berupa uji kualitatif golongan senyawa alkaloid, flavonoid, saponin, tanin, steroid, dan terpenoid

\section{Analisis Asiatikosida dengan Menggunakan Kromatografi Lapis Tipis \\ Pengujian analisis asiatikosida ini bertujuan untuk mengetahui seberapa banyak kadar asiatikosida dalam ekstrak kental herba pegagan. Serbuk sebanyak $0,25 \mathrm{~g}$ diekstrak dengan etanol $95 \%$, dan disimpan 1 malam kemudian disaring. Kemudian dielusi dengan eluen kloroform: etanol (6:4), ditambah $1 \mathrm{ml}$ etilasetat, menggunakan plate layer Aluminium-Silica (60 F 254) dan standarasiatikosida 100 ppm volume sampel (pentotolan) $5 \mu$ l. Setelah dielusi diukur dengan metode kromatografi lapis tipis (Thin Layer Chromatography Scanner/TLC Scanner) menggunakan panjang gelombang $276 \mathrm{~nm}$.}

\section{Analisis Antioksidan dengan Menggunakan Metode DPPH}

Analisis antioksidan ini dilakukan di Laboratorium Balai Penelitian Tanaman Rempah dan Obat. Jalan Tentara Pelajar No.3 Kampus Penelitian Pertanian Cimanggu, Kota Bogor. Pengujian analisis antioksidan ini bertujuan untuk mengetahui seberapa banyak aktivitas dalam ekstrak kental herba pegagan. Pada pengujian antioksidan ini dilakukan dengan cara metode DPPH.

a. Pembuatan larutan DPPH $(0,4 \mathrm{mM})$

Sebanyak 15,8 mg DPPH (BM 394,32 $\mathrm{g} / \mathrm{mol}$ ) ditimbang dan dilarutkan dengan metanol proanalisis hingga 100,0 ml serta ditempatkan dalam botol gelap.

b. Pembuatan larutan blangko

Sebanyak1 ml larutan DPPH $(0,4 \mathrm{mM})$ dipipet dan dimasukkan ke dalam labu terukur $5 \mathrm{ml}$ serta ditambahkan metanol hingga $5 \mathrm{ml}$ kemudian dihomogenkan dalam wadah gelap.

c. Pembuatan larutan induk vitamin $\mathrm{C}$

Larutan induk dibuat dengan cara ditimbang sebanyak $5 \mathrm{mg}$ vitamin $\mathrm{C}$, diarutkan dalam 5,0 ml metanol pro analisis (1000 bpj). Selanjutnya dari larutan induk dipipet sebanyak $10 \mu \mathrm{L}, 20$ $\mu \mathrm{L}, 30 \mu \mathrm{L}, 40 \mu \mathrm{L}, 50 \mu \mathrm{L}$ larutan induk ke dalam labu ukur $5,0 \mathrm{ml}$ untuk mendapatkan konsentrasi 2 bpj, 4 bpj. 6 bpj, 8 bpj. 10 bpj.

d. Pembuatan larutan uji

Larutan induk dibuat dengan cara dipipet $0,625 \mathrm{ml}$ larutan sampel, larutkan dalam 25,0 $\mathrm{ml}$ aquadest (1000 bpj). Selanjutnya dari larutan induk dipipet 50 $\mu \mathrm{L}, 100 \mu \mathrm{L}, 150 \mu \mathrm{L}, 200 \mu \mathrm{L}$ dan $250 \mu \mathrm{L}$ larutan induk ke dalam labu ukur 5,0 ml untuk mendapatkan konsentrasi sampel 10 bpj, 20 bpj, 30 bpj, 40 bpj dan 50 bpj.

e. Pengukuran aktivitas antioksidan

Ke dalam masing-masing labu ukur ditambahkan $1 \mathrm{ml}$ larutan DPPH 0,4 mM kemudian ditambahkan metanol sampai tanda 5,0 ml lalu dihomogenkan. Setelah homogen diinkubasi pada suhu $37^{\circ} \mathrm{C}$ selama 30 menit. Serapan diukur pada panjang gelombang $515 \mathrm{~nm}$.

\section{Formulasi Sediaan Losion}

Sediaan dibuat dengan menggunakan tiga basis yang berbeda masing-masing basis ditambahkan ekstrak kering herba pegagan sebanyak 5\%. Bahan-bahan dasar yang digunakan pada pembuatan losion ekstrak kental herba pegagan yaitu: Asam Stearat, Parafin cair, Setil alkohol, Gliserin, Trietanolamin, Metil paraben, Cera alba, Adepslanae, Propil paraben, Dinatrium EDTA, Pewangi, air suling disajikan pada Tabel 1. 
65 | Triyani Sumiati et al., (Formulasi Losion Ekstrak Herba Pegagan...)

Tabel 1. Formulasi Sediaan Losion

\begin{tabular}{|l|c|c|c|}
\hline \multicolumn{1}{|c|}{ Bahan } & Formula 1 & Formula 2 & Formula 3 \\
\cline { 2 - 4 } & Bobot $(\mathrm{g})$ & Bobot $(\mathrm{g})$ & Bobot $(\mathrm{g})$ \\
\hline $\begin{array}{l}\text { Ekstrak kental herba } \\
\text { pegagan }\end{array}$ & 5 & 5 & 5 \\
\hline Setil alkohol & 0,5 & - & 0,5 \\
\hline Asam stearat & 3 & 4 & 2 \\
\hline AdepsLanae & 1 & 2 & - \\
\hline Gliserin & 2 & 5 & - \\
\hline Metil paraben & 0,1 & 0,1 & 0,1 \\
\hline Trietanolamin & 1 & 1 & - \\
\hline Cera Alba & - & 2 & 7 \\
\hline Parafin Cair & - & - & 0,05 \\
\hline Propil paraben & 0,05 & 0,05 & 0,05 \\
\hline Dinatrium EDTA & 0,05 & 0,05 & q.s \\
\hline Aroma Green Tea & q.s & Sampai 100 & Sampai 100 \\
\hline Air suling & Sampai 100 & & \\
\hline Sumber: Mastan & & & \\
\hline
\end{tabular}

Sumber: Mastanir et al. (8)

\section{Evaluasi Sediaan Losion}

Evaluasi mutu losion dilakukan setelah sediaan terbentuk (minggu ke-0). Evaluasi meliputi: Uji penampilan fisik (organoleptik), pH, Viskositas, Daya Sebar, Daya Lekat.

\section{Uji Stabilitas}

Uji stabilitas ini dilakukan untuk mengetahui kualitas sediaan losion ekstrak kental herba pegagan berdasarkan organoleptik, viskositas dan $\mathrm{pH}$ selama penyimpanan dalam botol plastik putih. Pengujian ini dilakukan per minggu selama 8 minggu dengan suhu kamar yang berkisar antara $25-30^{\circ} \mathrm{C}$.

\section{HASIL DAN PEMBAHASAN Karakteristik Simplisia dan Ekstrak Bonggol Nanas}

Herba pegagan yang digunakan pada penelitian ini teridentifikasi dari jenis tanaman dari nanas dengan Centella asiatica (L.) Urb, suku Apiaceae. berdasarkan pada hasil determinasi tanaman oleh Herbarium Bogoriense, Bidang Botani Pusat Penelitian LIPI Bogor. Simplisia basah herba pegagan yang digunakan sebanyak $15 \mathrm{~kg}$, setelah dibuat menjadi serbuk dan diayak dengan mesh 40 diperoleh sebanyak 2,2 kg. Hasil perhitungan kadar air serbuk simplisia herba pegagan yang diperoleh sebesar 5,2 $\%$, halini menunjukkan serbuk simplisia herba pegagan memenuhi persyaratan. Serbuk simplisia yang diekstraksi sebanyak $1 \mathrm{~kg}$. Estrak kental diperoleh dari hasil maserasi kemudian dipekatkan menggunakan rotary evaporator pada suhu $50^{\circ} \mathrm{C}$ sampai diperoleh ekstrak kental. Ekstrak kental yang diperoleh sebanyak 214 gram dengan rendemen $21,4 \%$. Hasil dari serbuk simplisia ini berwarna hijau kecoklatan dengan berbau aromatik yang khas. Rendemen ekstrak herba pegagan tidak kurang dari $8 \%$ memenuhi persyaratan Monograph of Indonesian Medicinal Plant Extracts volume I. Serbuk simplisia dan Ekstrak Kental Herba Pegagan terdapat pada gambar 5.

\section{Penapisan Fitokimia}

Penapisan fitokimia dilakukan terhadap ekstrak kental untuk mengetahui golongan senyawa yang terkandung dalam herba pegagan. Hasil uji fitokimia ekstrak kental herba pegagan menunjukkan hasil positif pada senyawa golongan alkoloid, flavonoid, Saponin, Steroid, Triterpenoid, dan Tanin. Hasil uji fitokimia dapat dilihat pada Tabel 2. 
66 | Triyani Sumiati et al., (Formulasi Losion Ekstrak Herba Pegagan...)

Tabel 2. Hasil Uji FitokimiaEkstrak Kental Herba Pegagan

\begin{tabular}{|l|c|}
\hline \multicolumn{1}{|c|}{ Golongan senyawa } & Ekstrak Kental Herba Pegagan \\
\hline Alkaloid & + \\
$-\quad$ Bouchardat & + \\
$-\quad$ Mayer & + \\
$-\quad$ Dragendorf & + \\
\hline Flavonoid & + \\
\hline Saponin & + \\
\hline Steroid & + \\
\hline Triterpenoid & + \\
\hline Tanin & + \\
\hline
\end{tabular}

\section{Analisis Asiatikosida dengan}

Menggunakan Kromatografi Lapis Tipis

Asiatikosida merupakan senyawa aktif yang terkandung di dalam herba pegagan. Penetapan kandungan asiatikosida bertujuan untuk mengetahui banyaknya asiatikosida yang terdapat di dalam ekstrak. Penetapan kandungan asiatikosida dilakukan menggunakan Kromatografi Lapis Tipis (Thin Layer Chromatography Scanner/TLC scanner). Standar asiatikosida $100 \mathrm{ppm}$ dan sampel ditotolkan sebayak 5 $\mu 1$. Hasil penetapan kandungan asiatikosida pada ekstrak pegagan sebesar $1,22 \%$ (mg asiatikosida). Berdasarkan Monograph of Indonesia Medicinal Plant Extracts, kandungan asiatikosida pada ekstrak pegagan tidak kurang dari $0,9 \%$.

\section{Analisis Antioksidan dalam Herba Pegagan dengan Menggunakan Metode DPPH}

Pengujian aktivitas antioksidan daun pegagan dilakukan dengan menggunakan metode DPPH. DPPH merupakan zat oksidator yang dapat dijadikan radikal bebas pada pengujian aktivitas antioksidan. Penggunaan metode ini mudah, sederhana, peka, cepat dan memerlukan sampel yang sedikit. Pengujian dilakukan dengan menghitung nilai IC50, IC50 yaitu konsentrasi ekstrak uji yang mampu menangkap radikal bebas sebanyak 50\% yang diperoleh melalui persamaan regresi, semakin kecil nilai IC50 suatu senyawa uji maka senyawa tersebut semakin efektif sebagai penangkal radikal bebas (11). Hasil pengujian menunjukkan nilai IC50 serbuk daun pegagan sebesar 294,71 $\mu \mathrm{g} / \mathrm{mL}$, hal ini menunjukkan bahwa daun pegagan mampu meredam radikal DPPH dan kekuatan peredaman tergolong sebagai antioksidan yang sangat aktif.

\section{Evaluasi Sediaan Losion Ekstrak Kental Herba Pegagan}

Evaluasi losion ekstrak kental herba pegagan terdiri dari pengujian organoleptik meliputi warna, aroma, dan homogenitas sediaan. Evaluasi sediaan dapat dilihat pada Tabel 3.

Tabel 3. Evaluasi Sediaan Losion Ekstrak Kental Herba Pegagan

\begin{tabular}{|c|c|c|c|c|}
\hline \multirow{2}{*}{ Pengamatan } & \multicolumn{4}{|c|}{ Formula } \\
\cline { 2 - 5 } & Kontrol negatif & 1 & 2 & 3 \\
\hline Organoleptik & Putih susu & Hijau tua & Hijau tua & Hijau tua \\
\hline Warna & & Green Tea & Green Tea & Green Tea \\
\hline Aroma & Green Tea & Homogen & Homogen & Homogen \\
\hline Homogenitas & Homogen & Homog & 4,40 \\
\hline pH & 4,22 & 4,55 & 4,66 & $2500 \mathrm{cps}$ \\
\hline Viskositas & $2365 \mathrm{cps}$ & $1364 \mathrm{cps}$ & $2365 \mathrm{cps}$ & \\
\hline
\end{tabular}


67 | Triyani Sumiati et al., (Formulasi Losion Ekstrak Herba Pegagan...)

Tabel 4. Hasil Uji Daya Sebar

\begin{tabular}{|c|c|c|c|c|}
\hline \multirow{2}{*}{ Formula } & \multicolumn{4}{|c|}{ Diameter (cm) } \\
\cline { 2 - 5 } & 1 & 2 & 3 & Rata-Rata \\
\hline Kontrol - & 9,4 & 9,7 & 10 & 9,7 \\
\hline 1 & 9,4 & 9,6 & 9,8 & 9,6 \\
\hline 2 & 12,3 & 12 & 11,4 & 11,9 \\
\hline 3 & 8,9 & 9,3 & 10,3 & 9,5 \\
\hline
\end{tabular}

Dari tabel diatas menunjukkan hasil uji losion yang tersebar pada kulit. Uji daya sebar yang paling luas yaitu losion kelekatan losion penting untuk formula 2 dengan diameter rata-rata 11,9 mengevaluasi sejauh mana losion dapat $\mathrm{cm}$ dari semua sediaan lainnya, karena menempel pada kulit, sehingga efek terapi semakin luas daya sebar losion maka yang diharapkan bisa tercapai. semakin luas dan merata zat aktif dari

Tabel 5. Hasil Uji Daya Lekat

\begin{tabular}{|c|c|c|c|c|}
\hline \multirow{2}{*}{ Formula } & \multicolumn{4}{|c|}{ Waktu (Detik) } \\
\cline { 2 - 5 } & 1 & 2 & 3 & Rata-Rata \\
\hline Kontrol - & 1,15 & 1,23 & 1,19 & 1,19 \\
\hline 1 & 1,5 & 1,43 & 1,51 & 1,48 \\
\hline 2 & 1,68 & 1,65 & 1,74 & 1,69 \\
\hline 3 & 1,13 & 1,16 & 1,22 & 1,17 \\
\hline
\end{tabular}

Berdasarkan tabel hasil uji daya lekat diatas menunjukkan losion yang memiliki daya lekat paling lama yaitu formula 2 dengan waktu rata-rata 1,69 detik.

\section{Stabilitas Sediaan Selama 8 Minggu}

Pemeriksaan organoleptic dari sediaan losion ekstrak kental herba pegagan terdiri dari warna, aroma, dan homogenitas. Pengamatan kondisi fisik sediaan losion pada suhu kamar $\left(25-30^{\circ} \mathrm{C}\right)$ formula kontrol negatif, 1, 2 dan 3 tidak mengalami perubahan fisik pada warna, Perubahan aroma menjadi lebih lemah pada formula kontrol negatif tidak terjadi perubahan, pada formula 1 terjadi mulai pada minggu ke-6, pada formula 2 terjadi pada minggu terakhir dan pada formula 3 terjadi mulai pada minggu ke-7dan pada formula 1 dan 3 formula terjadi ketidakhomogenan selama penyimpanan. Pada pengujian warna tidak ada perubahan selama penyimpanan 8 minggu. Standar deviasi pada pengujian warna formula kontrol negatif, 1, 2, dan 3 adalah 0 hal ini menunjukan data yang ada memiliki nilai yang sama. Setelah penyimpanan lebih dari 8 minggu warna losion berubah menjadi lebih tua. Derajat keasaman $(\mathrm{pH})$ merupakan suatu parameter penting dalam analisis produk kosmetik karena $\mathrm{pH}$ dari kosmetik yang dipakai dapat mempengaruhi daya absorpsi kulit. Produk kosmetik $\mathrm{pH}$ yang sangat tinggi atau sangat rendah dapat meningkatkan daya absorpsi kulit sehingga menyebabkan kulit iritasi. Pengukuran $\mathrm{pH}$ dilakukan setiap 1 minggu selama 8 minggu menggunakan alat $\mathrm{pH}$ meter. 
68 Triyani Sumiati et al., (Formulasi Losion Ekstrak Herba Pegagan...)

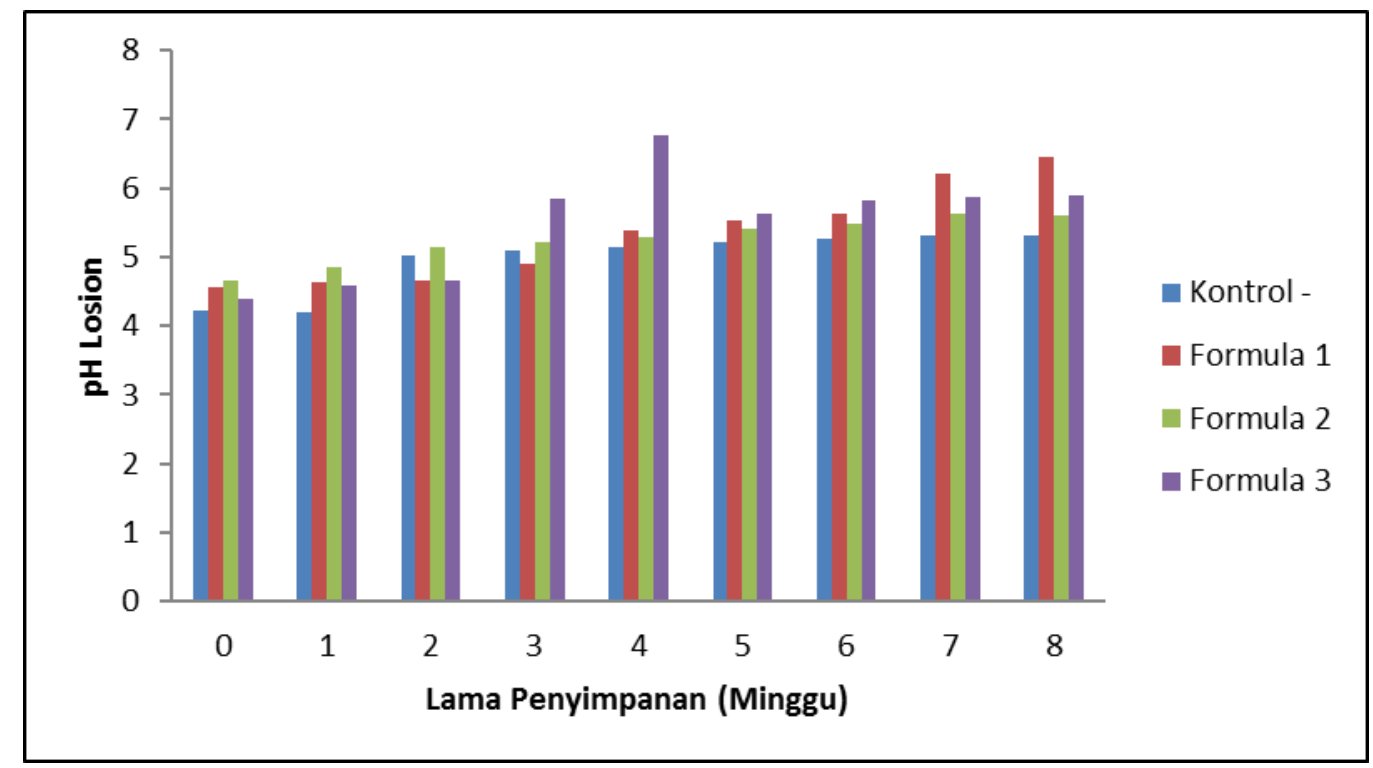

Gambar 1. Grafik hasil uji stabilitas pH sediaan losion

Pengukuran viskositas dilakukan setiap 1 minggu selama 8 minggu pada suhu kamar $\left(25^{\circ} \mathrm{C}-30^{\circ} \mathrm{C}\right)$.

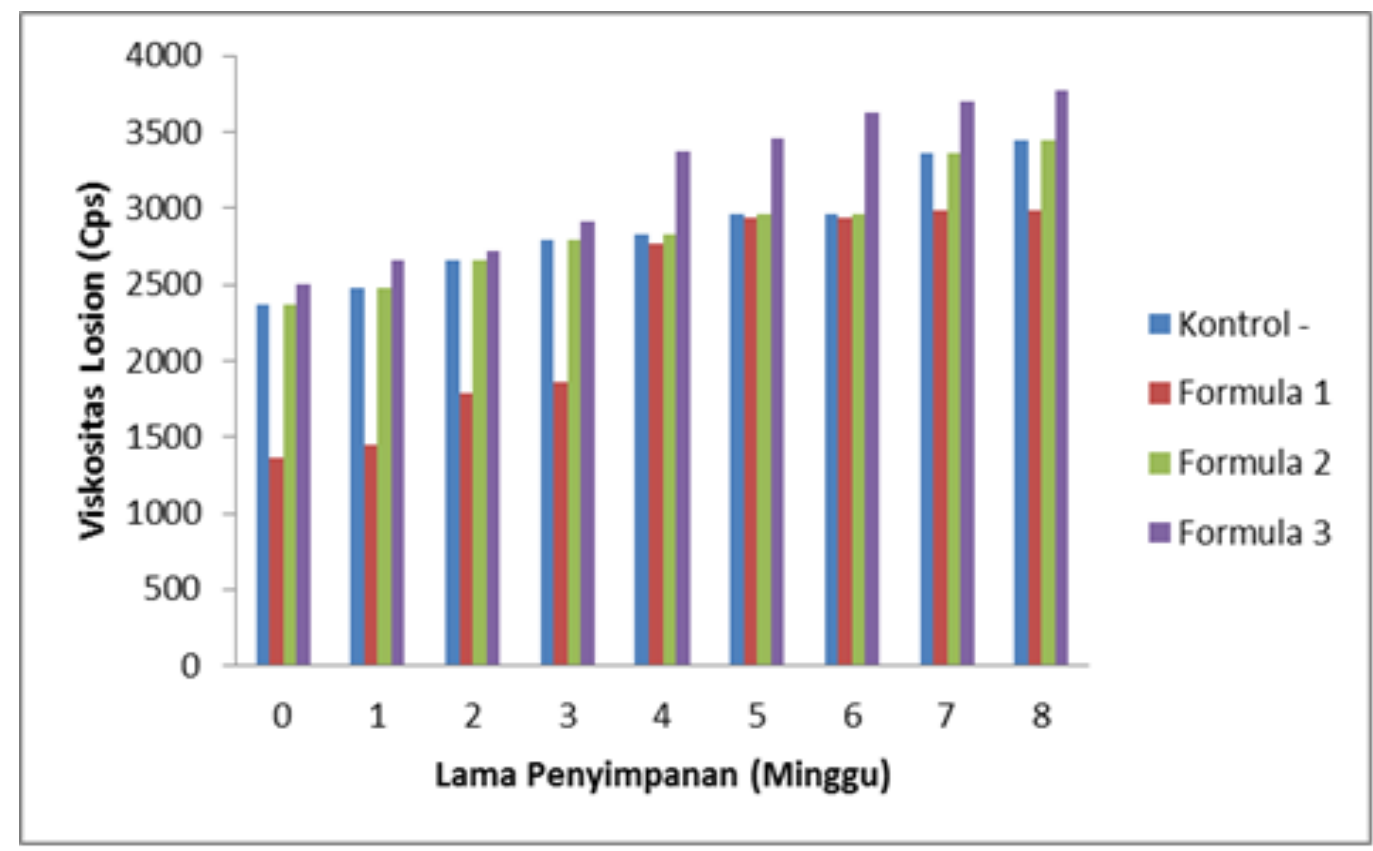

Gambar 2. Grafik hasil uji stabilitas viskositas sediaan losion

Berdasarkan grafik diatas hasil pengukuran viskositas losion ektrak herba pegagan yang diukur menggunakan alat viscometer brookfield., dapat dilihat formula 2 memiliki tahanan sediaan yang lebih tinggi dibandingkan dengan formula lainnya. Dari hasil pengukuran stabilitas selanjutnya dilakukan uji statistik untuk mengetahui apakah pada formulasi sediaan

losion herba pegagan terdapat perbedaan yang signifikan pada $\mathrm{pH}$, daya sebar dan viskositasnya. Uji statistic dilakukan dengan metode Two Way Anova dan selanjutnya dilakukan analisa menggunakan metode Duncan. Berdasarkan uji statistik menggunakan Two Way Anova yang dilanjutkan dengan uji Duncan menunjukan hasil yang berbeda dari setiap formula. 
69 | Triyani Sumiati et al., (Formulasi Losion Ekstrak Herba Pegagan...)

\section{SIMPULAN}

Simpulan yang didapat dari hasil penelitian ini adalah pada pengujian mutu fisik yang meliputi organoleptik, $\mathrm{pH}$, viskositas, daya sebar, dan daya lekat pada formula 2 memiliki mutu yang baik dibandingkan dengan formula 1 dan 3 . Uji stabilitas selama 8 minggu dengan penyimpanan di suhu kamar $\left(25-30^{\circ} \mathrm{C}\right)$ formula 2 menghasilkan stabilitas yang lebih baik dibandingkan dengan formula lainnya.

\section{DAFTAR PUSTAKA}

[1] Harborne, J.B., 1987, Metode Fitokimia, Edisi kedua, ITB, Bandung

[2] Krishnan, V.N., K.B. Soni\& K. Rajmohan. 2008. Agrobacterium Tumefaciens Mediated Genetic Transformation in Centella Asiatica (L.) Urban. Current Biotica.

[3] Winarto, W.P. dan M. Subekti. 2003. Khasiat dan Manfaat Pegagan: Tanaman Penambah Daya Ingat. Penerbit Agromedia, Jakarta.

[4] Anita, P. 2012. Pengujian Stabilitas Antioksidan pada Sediaan Cream
Ekstrak Herba Pegagan (Centella Asiatica) dalam lima basis yang berbeda. Universitas Pakuan. Bogor.

[5] Morwanti, A. D. 2006. Aplikasi Dimethicone (Silicone oil) Sebagai Pelembut dalam Proses Pembuatan Skin Lotion. Fakultas Teknologi Pertanian. IPB, Bogor.

[6] Departemen Kesehatan RI. 1985. Formularium Kosmetika Indonesia. Jakarta: Direktorat Jendral Pengawasan Obat dan Makanan.

[7] DepartemenKesehatan RI. 1995. Farmakope Indonesia. Edisi IV. Jakarta.

[8] Mastanir, Marianne, dan I. Harifsyah. 2011. Aktifitas Repellent Nyamuk Lotion KombinasiEkstrakBatang Vitex trifolia L. dan N, N-dietil-metatoluamida. Unsiyah, Banda Aceh.

[9] Endrini S, Marsiati H, Suherman J, Fauziah O, Asmah R. Aktivitas antioksidan dan efek sitotoksik ekstrak kola (Cola nitida) pada kultur sel kanker hati (HepG- 2). Jurnal Kedokteran Yarsi 2009;1743. 